\title{
Sudan Suakin Adasındaki Osmanlı Eserleri Mimari Özellikleri ve 3 Boyutlu Belgeleme Süreci
}

\author{
Gülhan BENLi ${ }^{1 *}$, Yeşim DOLUNAY YÜKSEL ${ }^{2}$, Serdar AYAN ${ }^{2}$
}

ÖZ

Suakin adası, Sudan'ın Kızıldeniz kıyısında, Portsudan'a 58 km. mesafede dünyaca önemli mercan kayalıkları üzerine kurulmuş bir adadır. Bu adanın en önemli özelliği, denizden çıkarılan mercan resiflerinden inşa edilmiş yapılarıdır. Stratejik konumundan dolayı, ticari olarak Afrika'nın içlerine açılan bir kapı işlevi gören ve bir zamanlar üzerinde birçok nitelikli yapının (konut, cami, banka, hastane, atölye, gümrük binası v.b.) bulunduğu ada, günümüzde harap durumdadır. Adanın üzerinde bulunan önemli yapılar arasında, 16 ve 17 . yüzyıllarda ada üzerinde hüküm süren Osmanlı İmparatorluğu döneminden kalan iki adet cami ve bir adet gümrük binası da yer almaktadır. Bu çalışmanın ilk bölümünde Osmanlı dönemi eserlerinin mimari özellikleri, ikinci bölümünde ise bu eserlerin 3 boyutlu lazer tarama teknolojisine dayalı belgeleme ve rölöve hazırlanma süreci aktarılacaktır.

Anahtar Kelimeler: Osmanlı eserleri, Suakin, 3B lazer tarama, sayısal rölöve, mercan taşlı yapılar.

\section{Architectural Characteristics of Ottoman Works and their 3 Dimensional Documentation Processes in Suakin Island in Sudan}

\begin{abstract}
Suakin Island is an island built on the worldwide important coral reefs on the Red Sea coast of Sudan, with $58 \mathrm{~km}$ distance to Portsudan. The most important feature of this island is the buildings built by coral reefs removed from the sea. The island, which is functioning as a door opening to inner Africa commercially due to its strategic position and which was full of many qualified structures (dwelling, mosque, bank, hospital, workshop, customs building etc.), has been in ruins nowadays. Among the important buildings on the island there are also a custom and two mosques left from the Ottoman empery period between the $16^{\text {th }}$ and $17^{\text {th }}$ centuries. Within the scope of this article, in the first part the information about architectural features of the Ottoman period buildings will be given and in the second part the documentation and the preparation of the surveying which based on 3D laser scanning technology will be described.
\end{abstract}

Keywords: Ottoman heritage, Suakin, 3D laser scanning, digital survey, coral buildings.

\footnotetext{
${ }^{1}$ İstanbul Medipol Üniversitesi,

${ }^{2}$ IBBB, Bimtaş A.Ş.,

* Illgili yazar/Corresponding author: gbenli@medipol.edu.tr

Gönderim Tarihi: 27.09.2017
}

Kabul Tarihi: 16.12.2017 
Sudan Suakin Adasındaki Osmanlı Eserleri Mimari Özellikleri ve 3 Boyutlu Belgeleme Süreci

Architectural Characteristics of Ottoman Works and their 3 Dimensional Documentation Processes in Suakin Island in Sudan

\section{1. ÇALIŞMANIN ARKA PLANI}

Sudan'da süren güney-kuzey çatışmaları uzun yıllar ülkeyi istikrarsız bir ortama sürüklemiş, çeşitli ara anlaşmalar yapılmışsa da barış bir türlü sağlanamamıştır. Yıllarca çok yıkıcı bir şekilde devam eden iç çatışmaların sürdüğü bu ortamda, şehirlerin, tarihin ve kültürün korunması için Sudan hükümeti tarafından büyük imkanlar ayrılamamıştır. 1973 ve 1993 yıllarında Unesco'dan gelen heyetler tarafından, Suakin Adası'nın dünya miras listesine alınması ve alanın korunması konusunda bazı gereklilikler istenmiş, ancak Sudan Hükümeti'nin bu konudaki çalışmaları yeterli olamamıştır (Hansen, 1973, s.3) (Arpa, 2009, s.3).

2009 yılında Türkiye hükümeti Suakin'deki Osmanlı eserlerine sahip çıkmak ve korunmalarına yönelik bir çalışma başlatmıştır. Türkiye, Suakin'de bulunan Osmanlı eserlerinin restorasyon çalışmalarını gerçekleştirmeye karar verdiğinde, Başbakanlığı'a bağıı "Türk İşbirliği ve Koordinasyon Ajansı Başkanlığı'ndan (TiKA) bir heyet, adaya giderek incelemelerde bulunmuştur. Suakin'de bulunan Hanefi Camii, Şafi Camii ve Gümrük binasının proje çalışmalarını hazırlamak üzere, haziran 2009'da, İstanbul Büyükşehir Belediyesi Bimtaş A.Ş. tarafından, dört adet y. mimar restorasyon uzmanı, bir adet inşaat mühendisi, bir adet harita mühendisi, üç adet harita teknikeri, bir adet peyzaj mimarından oluşan uzman teknik bir grup görevlendirilerek, bölgeye göndermiştir. Çalışma kapsamında mimari avan proje, rölöve, restitüsyon ve restorasyon projeleri ile elektrik, mekanik ve çevre düzenleme proje ve raporları oluşturulmuştur. Bu makale kapsamında aktarılan bilgiler, 2009-2010 yılında yapılan bu çalışmadan kazanılan deneyimlere dayanmaktadır.

\section{SUAKIN ADA'SININ KONUMU ve KISA TARIHÇESI}

Suakin adını farklı kaynaklarda "Sevakin", "Savakin", "Sevvakin", "Sawakın" olarak bulmak mümkündür (Salim, 1997, s. 63) (Hamadai, 1973, s. 5). Bölge, Sudan Hükümeti'nin ulusal müzesinde (National Museum of Sudan, Khartoum) Suakin olarak isimlendirildiğinden, bu makalede de Suakin olarak adlandırılmıştır. Sudan'ın doğusunda eski bir liman şehri olan Suakin, Kızıldeniz'in batı kıyısında yer alır ve Süveyş Limanı'ndan 1158 km, Cidde Limanı'ndan 321 km, Musavva Limanı'ndan 458 km, Portsudan Limanı'ndan ise 50 km uzaklıktadır (Salim, 1997, s. 65) (Şekil 1).

Eski kaynaklarda adanın tarihi hakkında fazla bilgiye rastlanmamıştır. IX. yüzyılda bölgede Hadendoa, Bisharin ve Amarar olarak bilinen kabilelerin yaşadığı, Suakin halkının bu kabilelerden oluştuğu öğrenilmektedir (Hale, 1976, s. 8). Kızıldeniz'de denizciliğin başlamasıyla birlikte adanın adı zikredilmeye başlanır. XIII. yüzyılın başlarında Zenci Hıristiyanların yerleşmiş olduğu ada, Mısır döneminde hükümdarın donanması için ticari bir üs görevi görmüştür. Bu dönemde Mısır hükümdarına vergi vererek göreceli bir bağımsızlığa kavuşur (Roden, 1970) (Rhodes, 2011, s. 165). Sonraki dönemde Arapların Afrika'ya gelmesi ve Müslümanlığın yayılmaya başlaması ile birlikte, kıtanın ortasında ve batısındaki Müslümanlar için bir hac kapısı olmuştur. Suakin'de günümüzde, yerli halk ve çevreden gelen göçmenler yaşamaktadır. Halkın oldukça zor geçindiği, sağlık ve eğitim hizmetlerinin bulunmadığı bölgede, yaşam oldukça zor şartlarda devam etmektedir. 


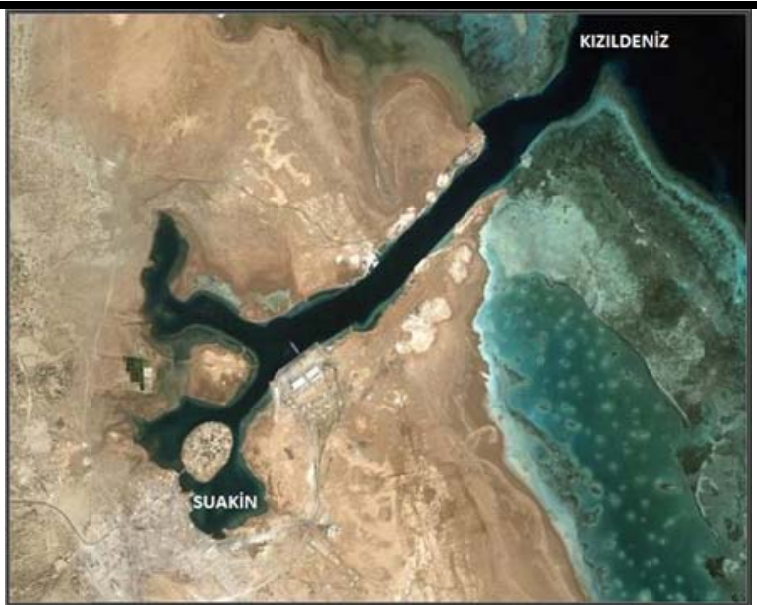

Şekil 1: Sudan Suakin Adası'nın konumu, anakara ve Kızıldeniz ile bağlantısı (URL-1, 2017)

\section{ADA ÜZERINDEKI OSMANLI ESERLERI}

Suakin adası Osmanlılar döneminde görkemli ve işleyen bir limanken tespit çalışmalarının yapıldığı tarihlerde yıkıntı durumunda bulunmuştur. 1940'lı yıllarda adada görevli bulunan İngiliz subayı J.P. Greenlaw'ın yapmış olduğu çizimlerden anlaşılabileceği gibi bir dönem ada üzerinde çok sayıda nitelikli yapı bulunmaktaydı (Greeenlaw, 1976, s. 6-16). Osmanlı'nın hakimiyetindeyken yapıldıkları tahmin edilen Hanefi Camii, Şafi Camii ve Gümrük binasının birbirine yakın ve adanın kuzey ucunda konumlandıkları görülmektedir (Şekil 2). Bu üç yapının genel fiziki ve korunmuşluk durumları, ada üzerindeki diğer yapıları göre çok daha iyi durumdadır. Yakın tarihe kadar kullanılıyor olmaları ve kamu yapısı olmalarına bağlı olarak yapım tekniğindeki kaliteli üretim, günümüze ulaşmalarındaki ana etken, sayılabilir.

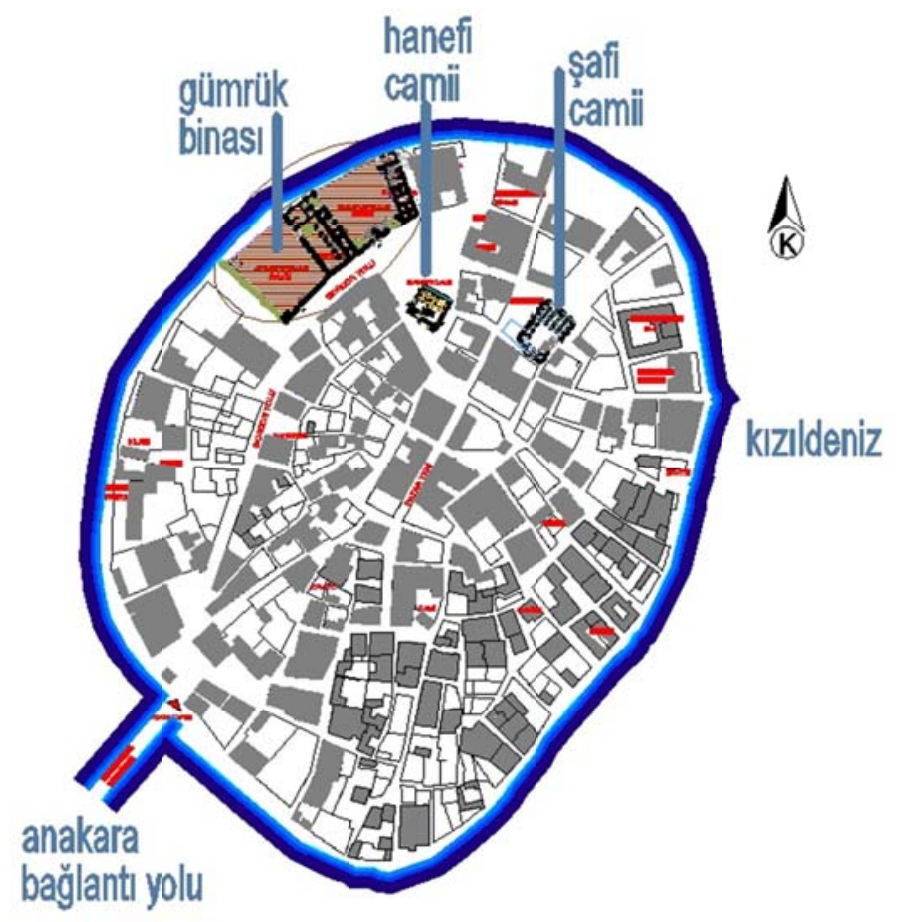

Şekil 2: Suakin adası vaziyet planı (Gülhan Benli, 2009) 
Sudan Suakin Adasındaki Osmanlı Eserleri Mimari Özellikleri ve 3 Boyutlu Belgeleme Süreci

Architectural Characteristics of Ottoman Works and their 3 Dimensional Documentation Processes in Suakin Island in Sudan

\subsection{Bölgeye yönelik alan araştırması}

Suakin'deki Osmanlı dönemi yapıları ile ilgili belgeleme çalışması kapsamında Sudan Hükümeti arşiv bilgilerinden faydalanılmıştır. Sudan'ın başkenti Hartum'da (Khartoum) bulunan Ulusal Müze, Kültür Bakanlığı, Turizm Müdürlüğü ve Türkiye Elçiliği ziyaret edilerek arşivlerinde bulunan, uluslararası mimarlık ve sanat tarihi çalışmaları, onarım ve restorasyona yön verecek daha önceki uygulamalar araştırılmıştır. Suakin yerel müzesine de ayrıca ziyarette bulunarak, bölgenin eski dökümanlarından faydalanılmıştır. Restitüsyon ve restorasyon projelerine yerel müzede bulunan eski fotoğraflar temel dayanak sağlamıştır.

\subsection{Hanefi camii ve mimari özellikleri}

Hanefi Camisi adanın ayakta kalan en sağlam yapısıdır. Yerel halk ile yapılan görüşmelere göre, 1983-1985 yıllarına kadar insanlar burada yaşamaya devam edilmiştir. Bölgede yapılan çalışma esnasında, çok fakir bir ailenin adada hâlâ yaşamakta olduğu tespit edilmiştir. Anakarada yaşayan az sayıdaki cemaat tarafından Cuma günleri Hanefi Cami'sinin halen kullanılıyor olması, yapının günümüze kadar ulaşmasındaki en etkili faktördür (Şekil 3).

Plan: Tek katlı olarak planlanan Hanefi Camisi yaklaşık $20.00 \times 22.30$ metre boyutlarda bir alana oturmaktadır. Dikdörtgen planlı ibadet kısmının önünde $11.00 \times 19.60$ metre boyutlarında dikdörtgen bir avlu bulunmaktadır (Şekil 4). İbadet mekanı avludan payeler ile ayrılır. Dörderli iki sıra halinde ve birbirine paralel olarak konumlanmış payeler, geniş sivri kemerleri taşır. Ön sıradaki payeler arasında, yüksekliği yerden 60 $\mathrm{cm}$ olan parapet duvarı bulunur (Şekil 4). Aynı zamanda bu sıranın orta hizasında müezzin mahfili yer alır. Tümüyle ahşap malzemeden yapılmış bu mahfil, caminin en fazla yıpranmış elemanıdır (Şekil 8). İbadet mekanının döşemesi, avludan $13 \mathrm{~cm}$. daha düşüktür ve düzgün dörtgen doğal taş kaplamalı zemin üzerinde hasır serilidir. Avlunun zemini ise, boyutları birbirine eşit olmayan amorf formda doğal taş kaplıdır. Avluyu, 75$80 \mathrm{~cm}$. kalınlığında, $230 \mathrm{~cm}$. yüksekliğinde çevreleyen yüksek bahçe duvarları ibadet mekanı duvarları ile birleşerek camiye bütünlük kazandırır (Şekil 5).

Cephe: Cephelere mimari özellik kazandıran eleman, düz lentolu ahşap pencere kapaklarıdır. İçlerinde ayrıca bir camlı doğrama bulunmayan bu pencereler, adada sıkça oluşan kum fırtınalarına bir önlem olabilmesi için kapaklı düşünülmüştür. Bu kapakların alt ve üst kısımları birbirinden bağımsız olarak açımaktadır. Kapakların orta aksına denk gelecek hizada, üst kotta (yerden yaklaşık $2.80 \mathrm{~m}$. yükseklikte) tepe pencereleri yer alır. Tepe pencerelerinde sabit ahşap ızgara bulunmaktadır (Şekil 6). Dıştan bakıldığında, kübik formlu caminin çatısı düz damdır. Kuzeydoğu cephesinden çatı hizasında dışarıya çıkan taş çörtenler cepheye ayrıca özellik katmaktadır. Caminin genel olarak taşıyıcı sisteminde herhangi bir sorun yoktur, ancak tüm sıvalarda dökülmeler mevcuttur.

Sıbyan Mektebi: Avlunun batı yönünde ve bahçe duvarına bitişik konumlanmış bulunan iki katlı sıbyan mektebi bulunmaktadır. Zemin katına ahşap tek kanatı bir kapı ile ulaşılan yapının üst katına 9 adet taş basamaklı bir merdiven ile çıkılır. Yapıda pencere boşlukları bulunmasına rağmen, daha önce bu boşluklara hiç doğrama takılmadığı dikkati çekmektedir.

Minare: Caminin güney yönünde, sekizgen planlı ve camiye bitişik yer alan minare, $15.70 \mathrm{~m}$. yüksekliğindedir. Cepheden çıkıntı yapan şerefesinin minare gövdesiyle birleştiği kısımda profilli silmeler yer almaktadır. Külahı da taş olan minarenin, ana beden duvarlarındaki ahşap hatıllar cepheye yatay düzlemde vurgu katmaktadır. 


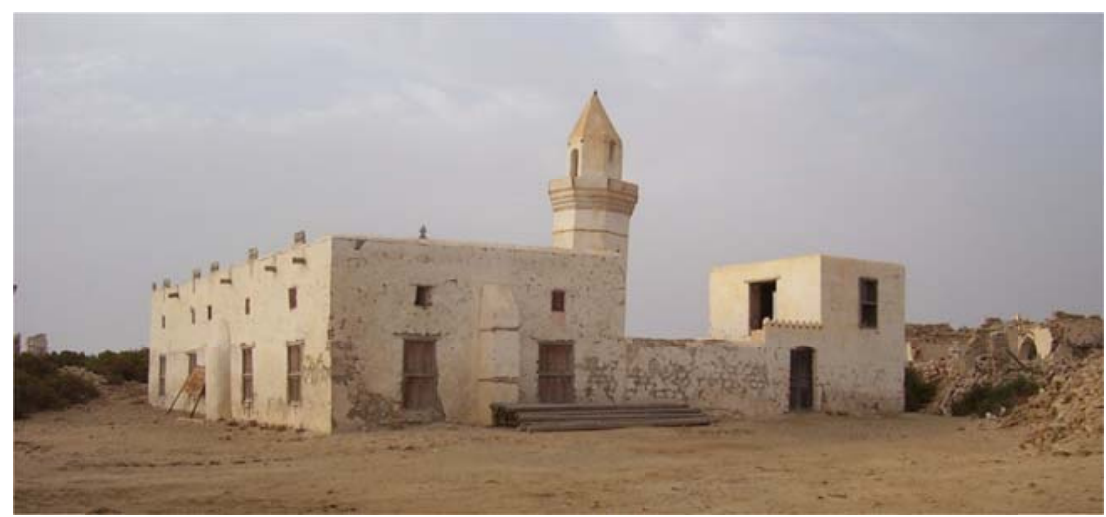

Şekil 3: Hanefi Camii ve sıbyan mektebi

(3)

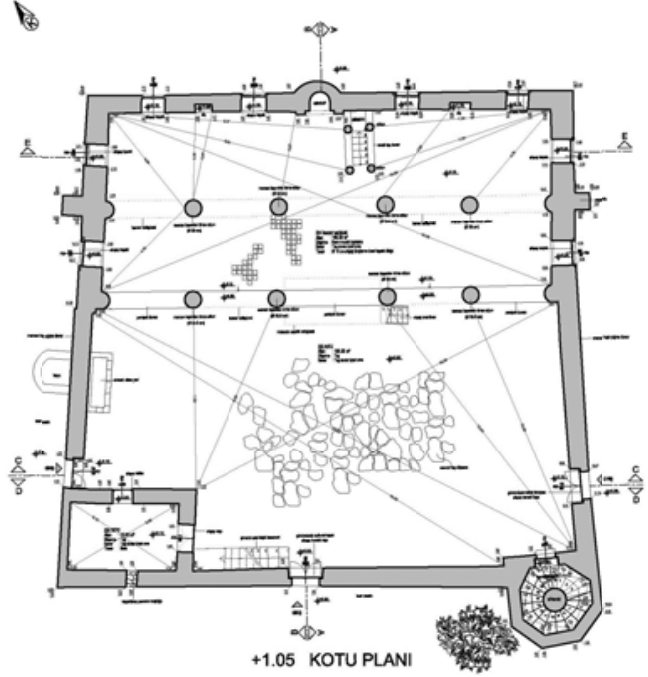

Şekil 4: Hanefi Camii plan rölövesi (nokta bulutu üzerinden yapılan CAD çizimi)

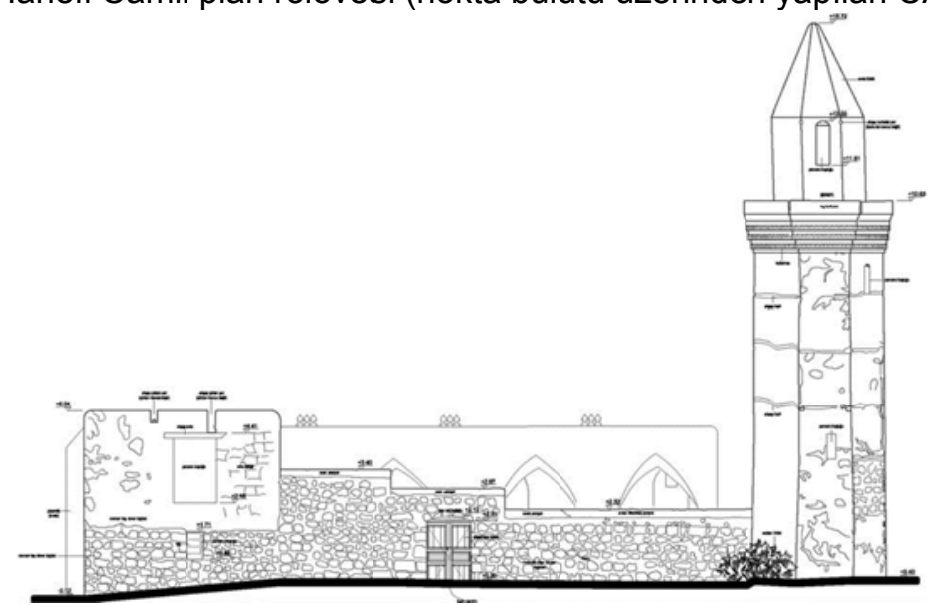

Şekil 5: Hanefi Cami arka cephe (güneybatı) rölövesi (nokta bulutu üzerinden yapılan CAD çizimi) 


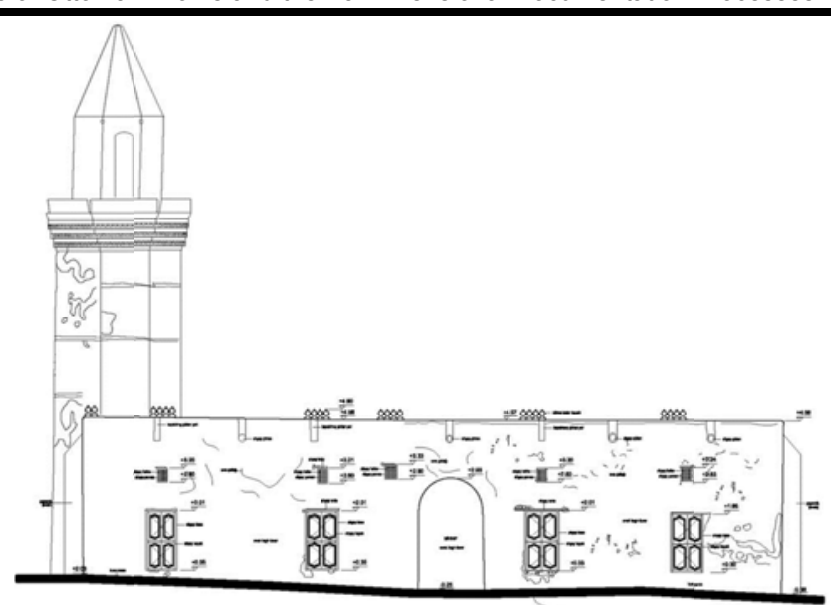

Şekil 6: Hanefi Cami ön cephe (kuzeydoğu) rölövesi (nokta bulutu üzerinden yapılan CAD çizimi)

\subsection{Gümrük binası ve mimari özellikleri}

Geçmişte Suakin'in, doğuda Hindistan ve Çin'e, güneyde Hartum ve Sennar, kuzeyde Kahire'ye, kuzeydoğuda Bağdat'a, güneyde Mombassa'ya kadar uzanan ticaret ağının merkezinde olduğu bilinmektedir (Mohammed, 2012, s. 69). Suakin'de ticaretin, deve ve yelkenli gemiler ile yapılan ulaşıma bağlı olduğu anlaşılan ticaret kapsamında tütsü ve baharatların güneyden geldiği, fildişi ve altın tozunun Suakin'den gittiği, çay, kahve, zencefil, seramikler, ipek gibi ürünlerin yanı sıra köle ticaretinin de yapıldığı öğrenilmektedir (Salim, 1997, s. 63-74). Bu denli yoğun ticari ürünün hem alışverişinin yapıldığı, hem de depolandığı gümrük binası, ada üzerindeki en büyük yapıdır.

Plan: Gümrük Binası, denize doğru dik konumlanmış iki büyük bina ve önlerindeki iki büyük avludan oluşmaktadır. Gümrük binasının yapılarından biri, ofis ve depo (1 no'lu bina), diğeri ise gümrük görevlilerinin yaşadıkları odalar (2 no'lu bina) olarak işlevlendirilmiştir. 1 no'lu gümrük binası (Şekil 7) 49.25 x 24.15 metre boyutlarında, yaklaşık 1175 m2lik bir alana oturmaktadır. 2 no'lu gümrük binası (Şekil 7) ise $44.50 \mathrm{x}$ 10.00 metre ölçülerindedir. Tek katlı olarak planlanan yapılar, avluları ile birlikte 5980 m2lik bir alana oturmaktadır. Yapılara yoldan doğrudan giriş yoktur, ulaşım avlulardan sağlanmaktadır. Avlulardan birinde gemilerle gelen malların boşaltılıp, gruplandırıldığı (avlu A) diğerlerinde ise develerle karadan gelen malların boşaltılıp (avlu B), depolandığı bölgede yapılan sözlü araştırmalardan öğrenilmektedir.

1 no'lu gümrük binası denize sıfır konumlanmıştır. Deniz içi derinliği kıyının hemen kenarında yaklaşık 30 - 35 metre derinliğe ulaşmaktadır. Bu sayede, ticaret gemileri avlunun yakınına kadar ulaşabilmektedir. Ancak belgeleme yapıldığı tarihte burada bulunması muhtemel iskelenin, yerinde olmadığı tespit edilmiştir. 2 no'llu bina önündeki avluya (avlu B) kemerli revaklar ile açılmaktadır. Bu binadaki bal peteği biçimindeki duvar örgüsü dikkat çekicidir. Ada üzerinde başka hiçbir binada bu tarz bir duvar örgüsüne rastlanmamıştır (Şekil 8). Özellikli bir işçiliğe sahip bu taş örgünün, özgün durumuna mı ait olduğu, yoksa sonraki dönemde mi değiştirildiği konusunda netlik oluşmamıştır. Ancak yapının çatısının tümüyle değişerek beton esaslı malzeme ile kaplandığı görülmektedir.

$\mathrm{B}$ avlusu olarak adlandırılan açık alan kum zemindir. Bu avluya 1 no'lu gümrük binasından açılan ahşap kayar kapı ile girilmektedir. B avlusunun esas giriş kapısı, güney yöndeki Gordon Yolu'ndan sağlanmaktadır. Deve kervanlarının bu kapıdan girdikleri ve B avlusunda barındıkları öğrenilmiştir. Gümrük binasının her iki yapısında da taşıyıcı sistem açısından çok büyük bir problem yoktur. Ancak sıvalarda ve kısmi olarak duvarların üst bölümlerinde dökülmeler mevcuttur.

Gümrük binasının iki adet girişi bulunmaktadır. İki giriş kapısının işlevleri birbirinden 
farklı olduğundan, mimari biçimlenişleri de farklıdır. Avlu A'ya açılan giriş kapısı, gümrük binasının esas girişini belirler. Profilli silme, kapının üç yönünü çevreler (Şekil 9). Profilli silme ve sivri kemeri giriş kapısının mimarisini tanımlar. Kapının üst kısmında ve orta noktasında metal rozet ve en üstünde günümüzde yerinde olmayan ahşap aslan heykeli bulunmaktadır. Aslan heykelinin ayaklarına ait bir bölüm kapının üstünde mevcuttur. Ancak geri kalan kısmı ada girişindeki güvenlik odasında muhafaza edilmektedir. Zemin kotundan yaklaşık $7.20 \mathrm{~m}$. yükseklikte biten giriş kapısı, yan duvarlara S biçimli profilli silme ile birleşir (Şekil 9 ve 10). Buradaki giriş kapısının ahşap ve iki kanatlı olduğu düşünülmektedir. Ancak ölçü alındığı tarihte yerinde bulunmamaktadır.

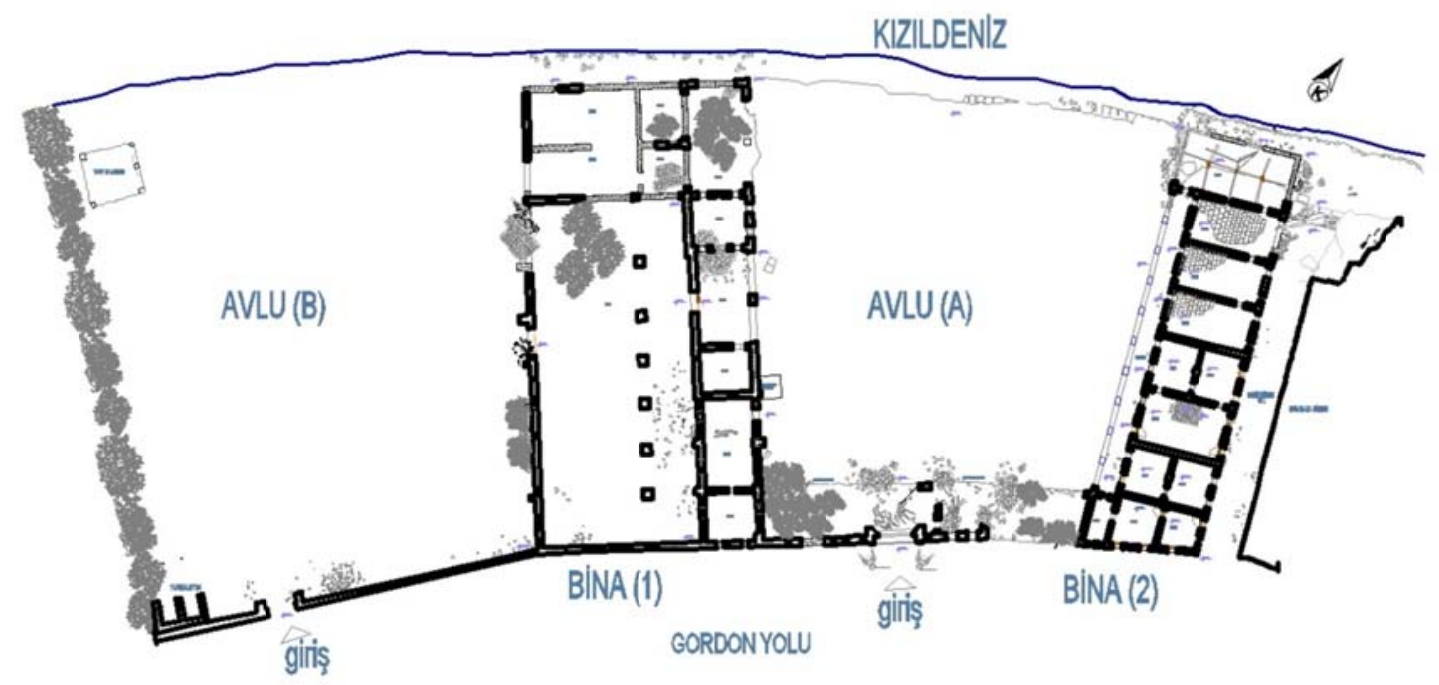

Şekil 7: Gümrük Binası plan rölövesi (nokta bulutu üzerinden yapılan CAD çizimi)

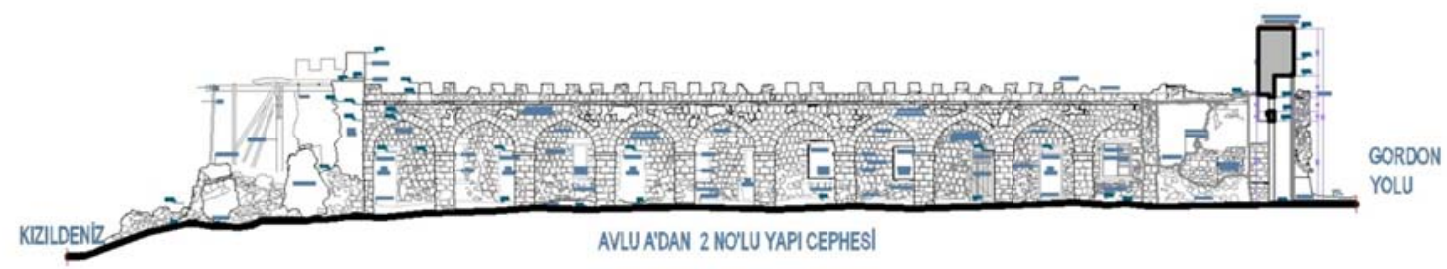

Şekil 8: Gümrük Binası A avlusundan kesit / 2 no'lu bina cephe rölövesi (nokta bulutu üzerinden yapılan CAD çizimi)

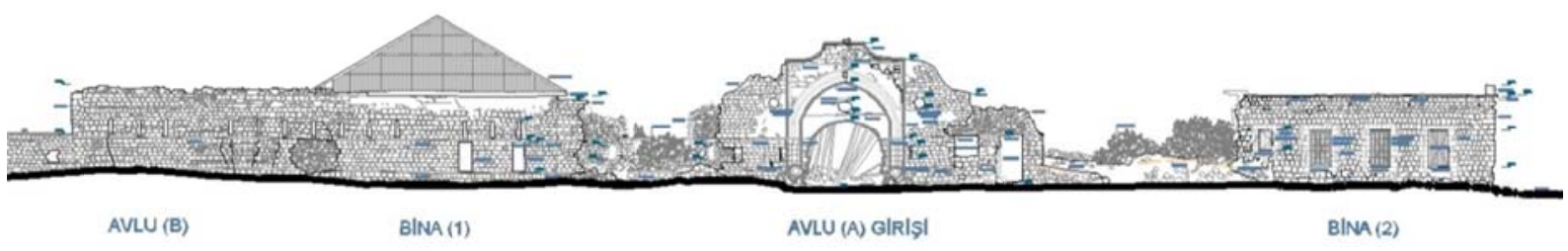

Şekil 9: Gümrük Binası güneybatı cephe rölövesi / Gordon Yolu cephesi (nokta bulutu üzerinden yapılan CAD çizimi) 


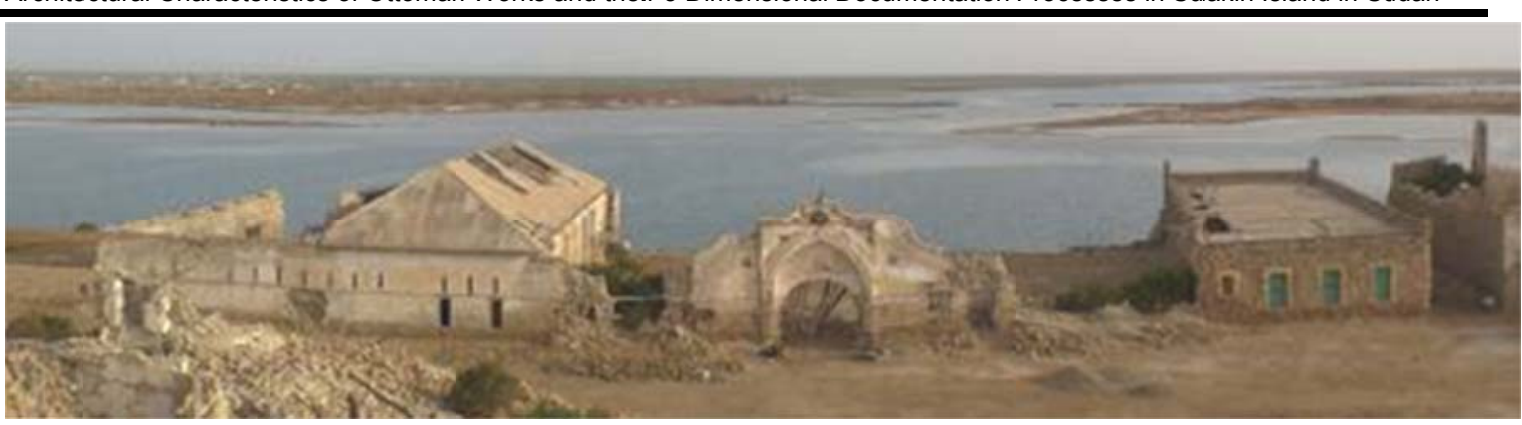

Şekil 10: Osmanlı Dönemi Gümrük Binası genel görünüşü

\section{4 Şafi camii ve mimari özellikleri}

Ana beden duvarlarındaki yıkım ve tahribatlar nedeniyle, belgelemiesi yapılacaklar arasında, ölçümleri en sona bırakılan Şafi Camisidir. Adanın en büyük camisi olmasına rağmen, bakım-onarım açısından halk tarafından gereken ilgiyi görmemiştir (Şekil 11).

Plan: Tek katlı olarak planlanan cami, yaklaşık $36.00 \times 22.50$ metre boyutlarında bir alana oturmaktadır. Mihrap cephesi dışında caminin üç yönden girişi bulunmaktadır. Mihrap cephesi (kuzeydoğu) yönünde ve mihraba paralel üç sıra nef yer alır. Nefleri oluşturan kemer sıraları, dört sıra halindeki payelere oturur. Düzgün olmayan ancak yine de sekizgen plan gösteren payeler, yaklaşık $100 \times 70 \mathrm{~cm}$. ölçülerine sahiptir. Rölöve ölçümü esnasında her payenin farklı ölçülerde olduğu tespit edilmiştir. Bu duruma ilk uygulama sırasında kalıp kullanılmadan yapılması ya da uygun işçilik ile örülmemiş olması neden gösterilebilir. Payelerin ve payelerin taşıdığı kemerlerin ölçü alımı sırasında şakülünde olmadığı tespit edilmiştir. Dikdörtgen planlı caminin içinde yaklaşık 12.00 x 18.00 metrelik avlu bulunmaktadır (Şekil 12). Av/unun içten, üç cephesini saran paye sırası bulunur. Bu payeler camidekilerden farklı olarak dikdörtgen planlıdır. Payelerin taşıdığı kemerler üç yönde birer revak oluşturur. İki yöndeki revaklı bölüm büyük oranda ayakta olsa da, güneydoğu yönündeki revaklı bölüm tümüyle yıkılmıştır. Kemerler arasında ahşap gergiler bulunmaktadır. Özgün mimarinin bir parçası olan bu gergilerden bazıları yerinde yoktur. Cami avlusunun zemini, farklı boyutlarda ve amorf biçimlerde taş ile kaplıdır.

Belgeleme çalışması esnasında caminin büyük oranda harap olduğu tespit edilmiştir (Şekil 13). Bazı ayak ve kemerlerde, yerel hükümet tarafından ahşap destekler ve çapraz gergiler ile yıkılmaya karşı önlem alınmıştır. Restorasyon aşamasında bu ahşap desteklerin yerinden alınmasında, kemerlerin yıkılmaması için, planlı ve sıralı davranılmalıdır. Mihrap ve minber büyük oranda tahrip olsa da yerinde mevcuttur.

Cephe: Cami dış duvarlarının büyük bölümü yıkıldığından, cephedeki pencere düzeni net olarak belirlenememiştir (Şekil 14). Avludan bakıldığında cami ibadet bölümünün revaklı cephesi mimari açıdan en fazla fikir veren cephedir. Sıvaların büyük kısmı döküldüğünden düzensiz taş örgü açığa çıkmıştır. Ada üzerindeki diğer yapılarda olduğu gibi, bu caminin de yapı malzemesi denizden çıkartılmış mercan taşıdır.

Cami ibadet mekanı üzeri ve avluyu saran tüm revaklı bölümler, düz dam ile örtülüdür. Tespitler esnasında yıkık olan çatının, ayakta kalan kısmi parçasından görülebildiği üzere, açıklıklar daire kesitli (yaklaşık $12-15 \mathrm{~cm}$ çapında) ahşap kirişler ile geçilmiştir. Bu kirişlerin üzerinde ters yönde döşenmiş, yaklaşık $2.5-3.00 \mathrm{~cm}$. kalınlığında ahşap kaplama tahtaları bulunmaktadır. Kaplama tahtalarının üzerinde toprak dam yer alır. Toprak damı oluşturan birleşimde, mercan taşının ufaltılmış parçaları ve ezilmiş mercan kumu karışımı mevcuttur. Ölçüm yapıldığında $10-15 \mathrm{~cm}$. kalınlık tespit edilen mevcut toprak dam çatı örtüsünün, gerçekte daha kalın olduğu, zamanla aşınarak inceldiği ve döküldüğü düşünülmektedir. Toprak damın sonraki dönemlerde daha kalın 

sıvanarak tamamlandığı ve çörten parçaların bu aşamada kaldırıldığı düşünülmektedir.

Caminin birçok bölümünde zaman içerisinde yapılan onarımlar göze çarpmaktadır. Bu onarımlarda bölgede mevcut bulunan mercan taşı kullanılsa da, arada kullanılan bağlayıcı harcın ve sıvanın çimento esaslı olduğu gözlenmiştir.

Güneybatı cephesinde bulunan ana giriş kapısı, diğer giriş kapılarından süsleme özellikleri bakımından farklılık gösterir. Ana giriş kapısı, iç içe geçmiş kemerler, sıvada yapılmış yivler, çiçekli armalar, güzbezekler ile çok özenli yöresel bezeme örnekleri sergiler.

Minare: Caminin güneybatı cephesine en büyük özelliği katan mimari öge, minaredir (Şekil 14). Girişi cami avlusundan olan minarenin yüksekliği 17.00 m.yi bulmaktadır. Minarenin girişinde sadece kapı boşluğu vardır, kapı doğraması yoktur. İçeriden dönerek çıkan merdivene gün ışığı girmesi amacıyla, cephede dar pencere boşlukları açılmıştır. Pencere boşluklarında doğrama, özgün durumunda da bulunmaz. Şerefenin altındaki mukarnaslarda bozulmalar olsa da, özgün biçimleri algılanabilmektedir. Şerefe kotuna bir adet dar kapı ile ulaşılır. Şerefe katını çevreleyen duvarlarda, yine doğraması olmayan pencere boşlukları bulunmaktadır. Şerefeyi çevreleyen ahşap korkuluk mevcut değildir. Minare, taş külah ve onun da üzerinde burgulu taş alem ile sonlanmaktadır. İçten ve dıştan sıvalı olan minarenin iç sıvaları mevıcuttur ancak dış sıvaları büyük oranda dökülmüştür. Dış cephede yapım sistemi olariak belli kotlarda bulunan ahşap hatıllar açığa çıkmıştır.

Sıbyan Mektebi: Caminin bitişiğindeki sıbyan mektebinin, 1865 yılında Mısır'dan Hidiv İsmail Paşa'nın bölgeye atandığı dönemde yapıldığı düşünülmektedir. Sıbyan mektebine ait ayakta kalan duvar mevcut olmasa da yapının temel izleri mevcuttur.

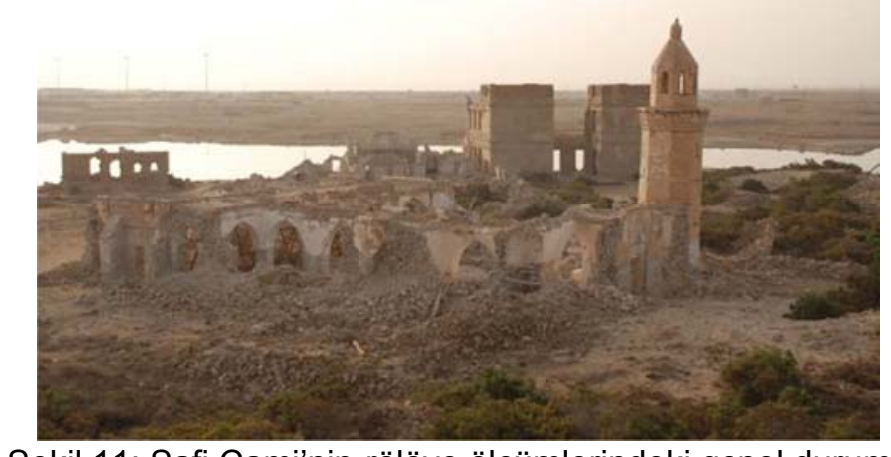

Şekil 11: Şafi Cami'nin rölöve ölçümlerindeki genel durumu 


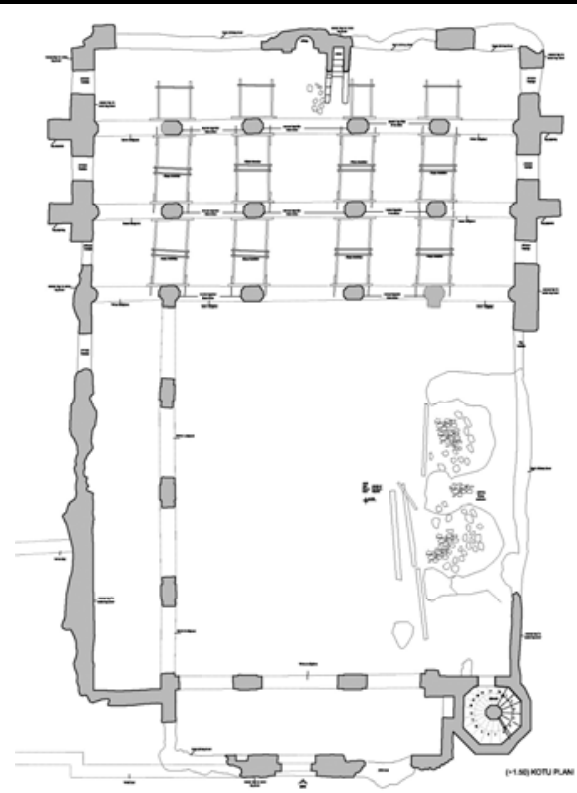

Şekil 12: Şafi Cami plan rölövesi (nokta bulutu üzerinden yapılan CAD çizimi)

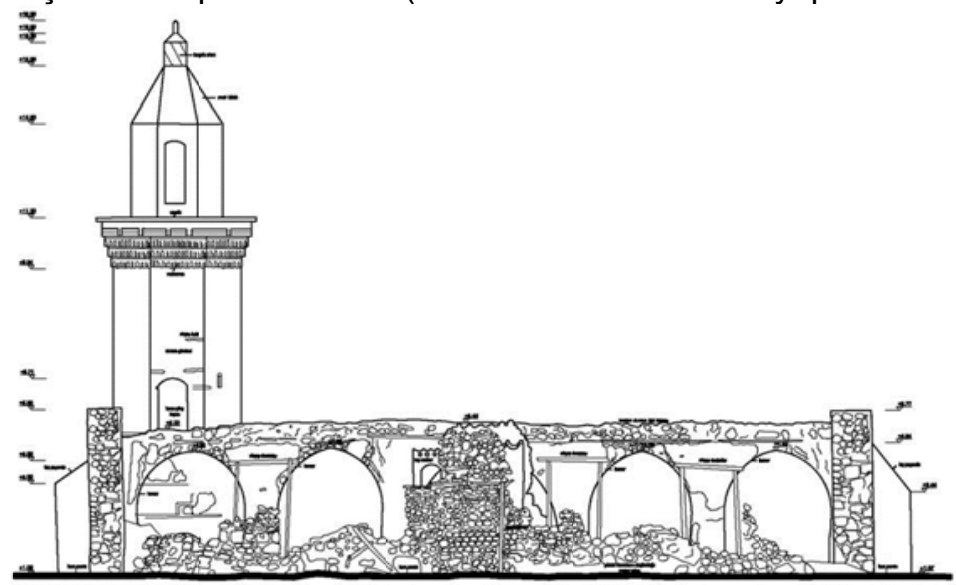

Şekil 13: Şafi Cami kesit rölövesi (nokta bulutu üzerinden yapılan CAD çizimi)

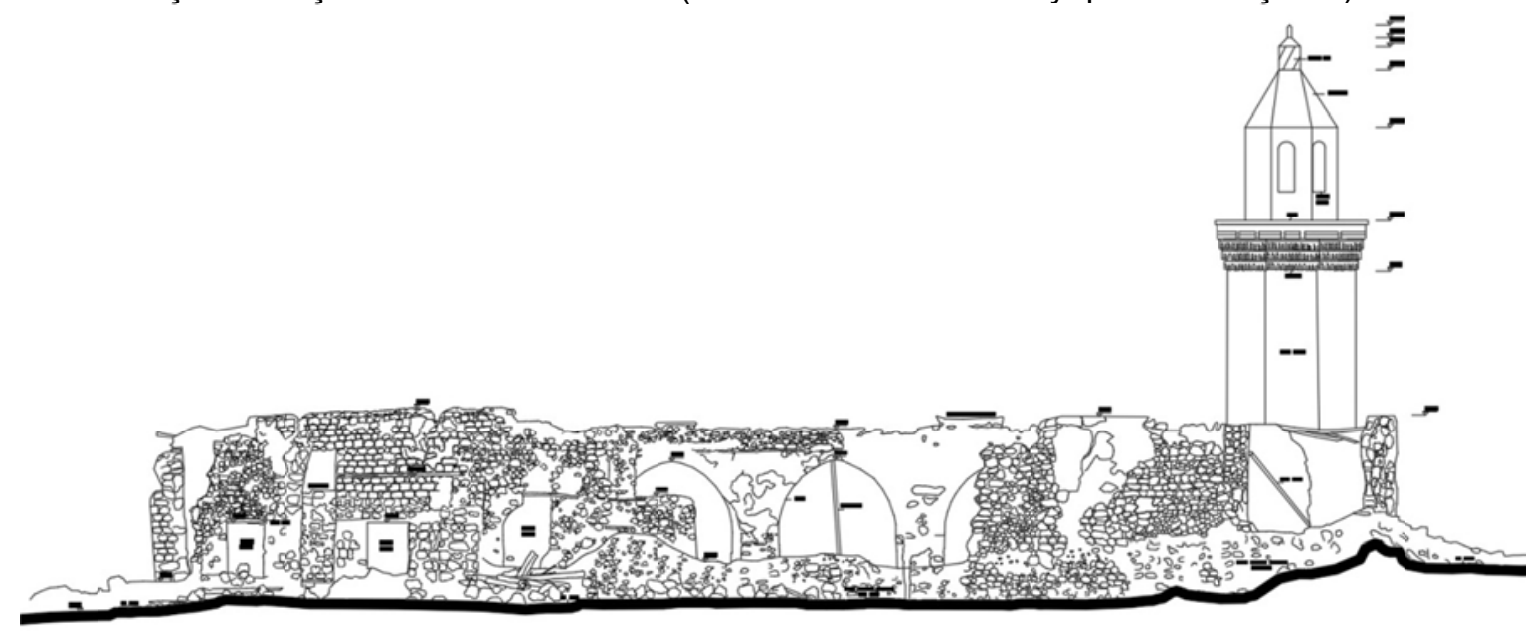

Şekil 14: Şafi Cami kuzeydoğu cephesi (nokta bulutu üzerinden yapılan CAD çizimi) 


\section{3 BOYUTLU BELGELEME SÜRECI}

Tarihi alanların belgelenmesinde, bilimsel yöntemler arasında yer alan 3 boyutlu lazer tarama teknolojileri, hızlı, doğru ve yoğun veri üretimi nedeniyle, tüm dünyada 2000'li yıllardan beri sıklıkla tercih edilir durumdadır. Lazer tarama teknolojilerinden elde edilen verilerden, uygun yazılımlar aracılığı ile 3 boyutlu çizim - haritalama - modelleme ve sayısal orto görüntüler üretilebilir hale gelmiştir. 3 boyutlu nokta bulutu olarak elde edilen küme içindeki noktaların her biri 3 boyutlu kartezyen koordinatlara ( $x, y, z$ değerlerine) sahip olduğundan, taraması yapılan yüzey, birkaç dakika içerisinde milyonlarca 3 boyutlu koordinat ile tanımlanabilmektedir (Benli ve Özer, 2013, s. 447).

\section{1 Çalışma metodolojisi}

Suakin'de bulunan üç adet yapının rölöve alım süresi yaklaşık yirmi gün olarak belirlendiğinden, bu kısa zaman zarfında geleneksel yöntemler ile rölöve alımının gerçekleştirilmesi oldukça zor bir durumdu. Bu nedenle rölöve alınmasına yönelik yapılan programda bir adet lazer tarama cihazı ve bir adet total station cihazının da kullanılmasına karar verilmiştir.

Suakin'de arazi çalışma şartları oldukça zorlu olduğundan, gidilen tarih itibariyle (haziran ayı) dış ortam sıcaklığı yaklaşık 45-48 derecelere sahipti. Kullanılan Lazer tarama cihazının hava sıcaklığının 40 derecenin üzerinde çalışması durumunda hatalı veri üretmesi olasılığı bulunmasına karşın, nispeten daha serin saatlerde gerçekleştirilecek ölçümlere göre çalışma programı güncellenmiştir. Çalışma programı olarak 04.00-10.00 ve 16.00-21.00 saat aralığı belirlenmiştir. Rölöve ölçüm programda özgün mimari özelliklerini en iyi koruyan Hanefi Camisi ilk sırada yer almıştır. İkinci sırada Gümrük Binası, tahribat oranı en yüksek olan Şafi Camisi ise en son sırada yer almıştır. Ekip uzmanlık alanlarına göre; lazer tarama ve total station cihazları ile hem mekânsal ve hem de bütüncül ölçüleri alan A grubu, geleneksel yöntemler ile eksik kalan detay ölçümlerini yapan B grubu, bölge ve yapılar hakkında bilgi ve belge toplayan $\mathrm{C}$ grubu olarak gruplara ayrılmıştır.

\subsection{Kullanılan ekipman ve yazılımlar}

Çalışma sırasında nokta bulutu taramaları için LEICA HDS 4500 lazer tarama cihazı kullanılmıştır (şekil 15). Elde edilen nokta bulutlarının işlenmesi, optimize edilmesi ve nokta bulutunun başka programlara aktarımı gibi tüm işlemler LEICA CYCLONE 8.0 yazılımında gerçekleştirilmiştir. Farklı istasyonlardan gelen tarama verileri ve topoğrafik koordinatlar, leıca cyclone 8.0'e aktarılarak tek bir koordinat sisteminde birleştirilmiştir. $\mathrm{Bu}$ birleştirme, iki tarama istasyonu arasındaki ortak noktaların tanımlanması ve birbirleri üzerine bindirilme yöntemi ile oluşturulmuştur. Hazırlanan renkli ve gri tonlamalı nokta bulutu verileri, mimari çizimlerin yapılabilmesi için AutoCad programı altında çalışan ve aynı zamanda vektörel bir yazılım olan ZMAP arayüz programına aktarılmıştır.

Yapıların fotoğrafları kalibre edilmiş Nikon D-90 metrik kamera ve $14 \mathrm{~mm}$.'lik geniş açılara sahip, kalibre edilmiş lens ile çekilmiştir. CAD ortamında hazırlanan rölöve çizim sürecinde, nokta bulutunda net görülemeyen detaylar için, yüksek çözünürlükte harici metrik kamera ile çekilen fotoğraflar ve bu fotoğrafların birleştirmesi ile oluşturulan ortofotolardan destek alınmıştır. Böylelikle, yapılara ait rölöve çizimleri kapsamında yüksek doğrulukta plan, kesit ve görünüş altıkları oluşturulabilmiştir. 


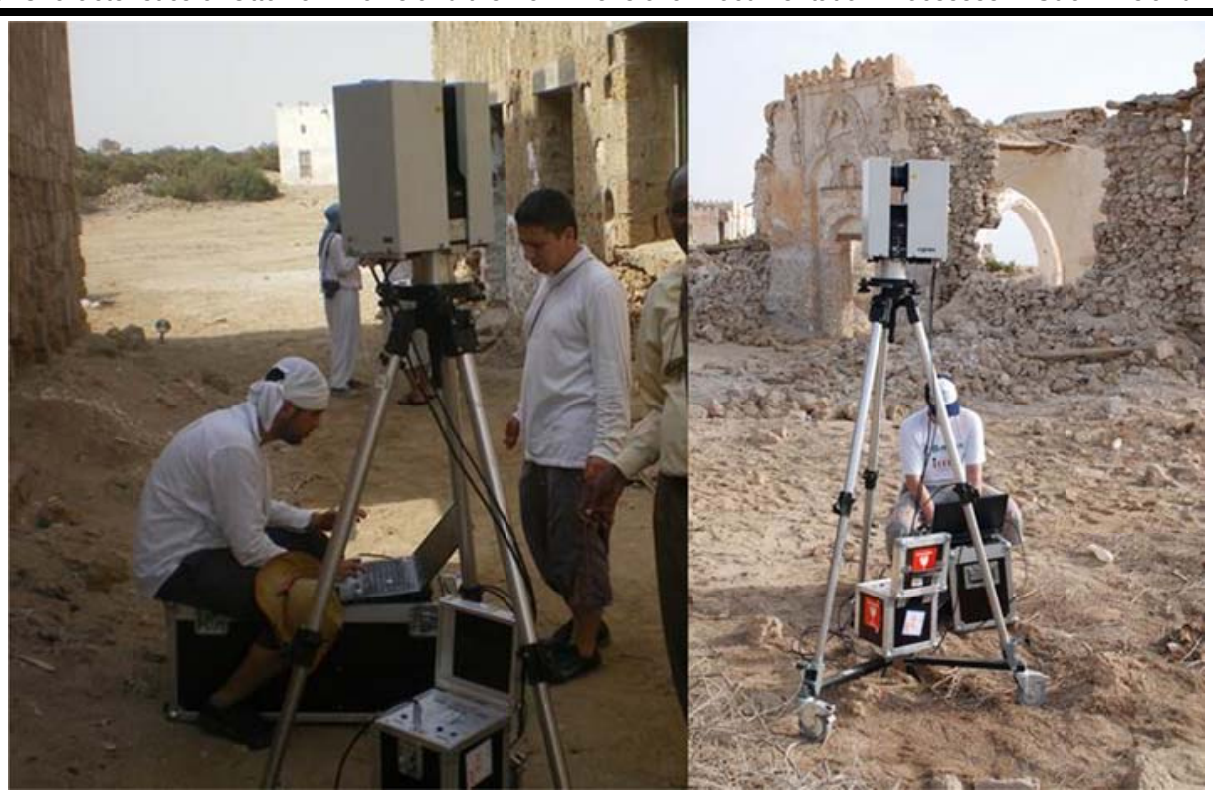

Şekil 15: Arazi çalışmalarında kullanılan lazer tarama cihazı

\subsection{CAD çizimleri (fotoğraf destekli nokta bulutu üzerinden 3 boyutlu vektörel rölöve çizimi )}

Rölöve alımında verilmesi gereken kararlardan biri; çizimi yapılacak yüzeyin hazırlanacağı ölçek kararı ve ekindeki detay çizimlerinin çeşitleridir. Yapının cephesindeki mimari öğelerin iç bükey yada dış bükey kıvrımlarının detaylarının net olarak okunabilmesinde, lazer ışığının yüzeye gidiş açısı önemli bir rol oynar. Cepheye 90 derece dik yapılan taramalarda daha net nokta bulutu görüntüsü elde etmekle birlikte, tarama açısının uygun olmadığı durumlarda birden fazla sayıda tarama yapılarak veriler birleştirilir ve bu veriler ofis ortamında koordinatları belli olan diğer veriler ile çakıştıııır. Suakin'deki yapıların cephe yükseklikleri 5-6 metreyi geçmediğinden, minarelerin dışında tüm yüzey taramalarında istenilen verim sağlanabilmiştir (Şekil 16).

Rölöveler, dört adet lisanslı İtalyan Menci-software firmasının Z-MAP programını kullanarak 3 boyutlu nokta bulutu verileri üzerinden çizilmiştir. Şekil 17'de nokta bulutu üzerinden yapılan CAD çizimlerinde taş dokudaki derzlerin detayları görülebilmektedir (Şekil 17). Şekil 18'de ise, Hanefi Camisinin bütün olarak görülebildiği, plan, kesit ve cephe rölöve çizimleri için altlık oluşturan 3 boyutlu telkafes (wireframe) verisi görülebilmektedir (Şekil 18). Çalışma metodolojisinde uygulanan sıralama, şekil 19'da diagramda ifade edilmiştir (Şekil 19).

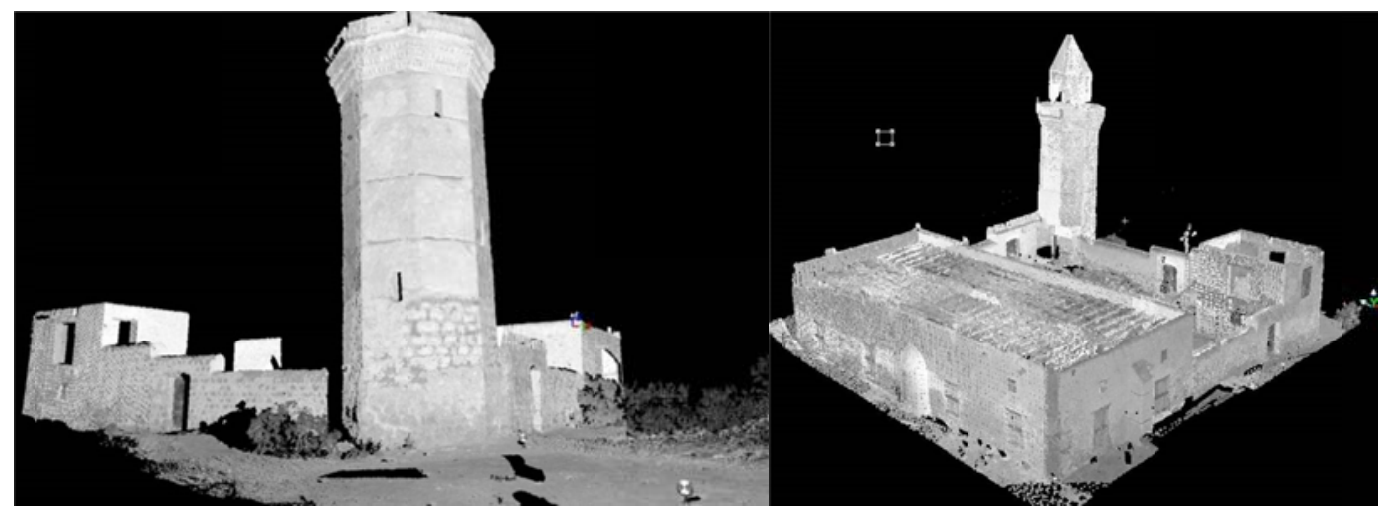

Şekil 16: Hanefi Camisine ait renksiz nokta bulutu görüntüleri 


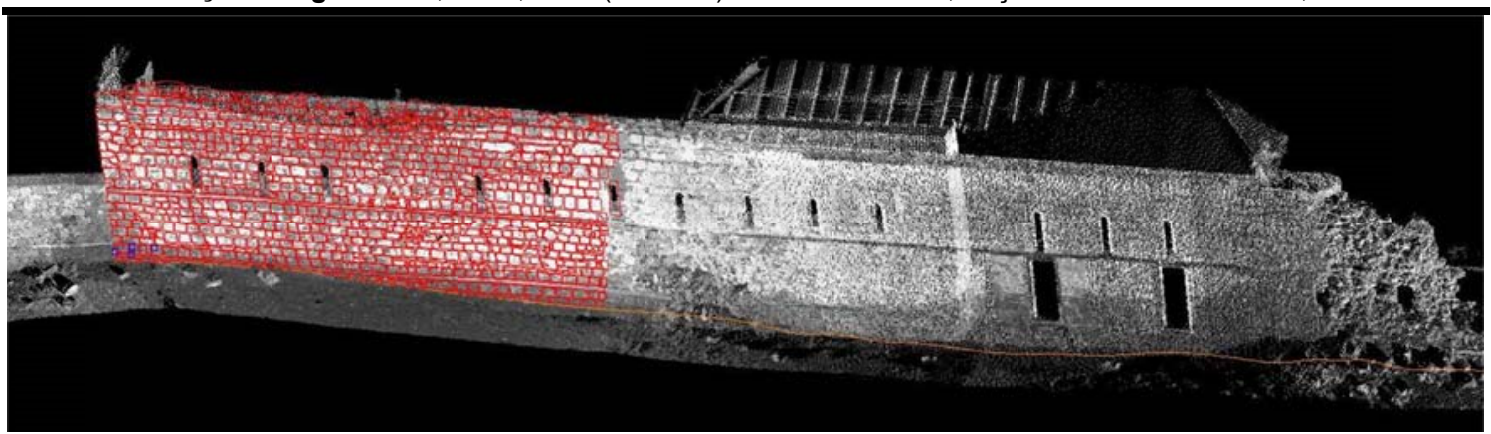

Şekil 17: Nokta bulutu üzerinden detaylı cad çizimleri yapılan Gümrük binası ön cephesi

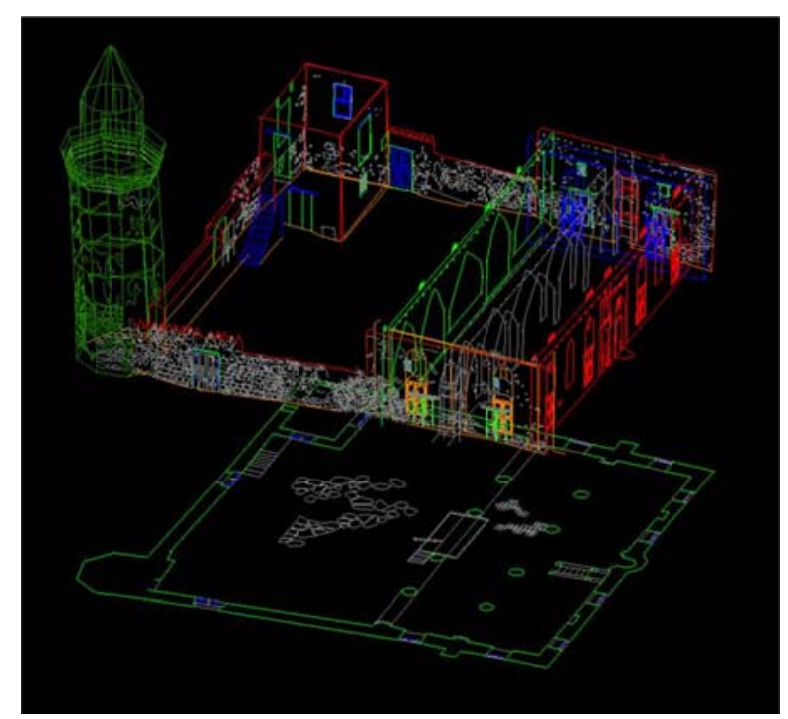

Şekil 18: Hanefi cami plan, cephe ve kesitlerin bir arada görünebildiği 3 boyutlu telkafes (wireframe) CAD çizimi

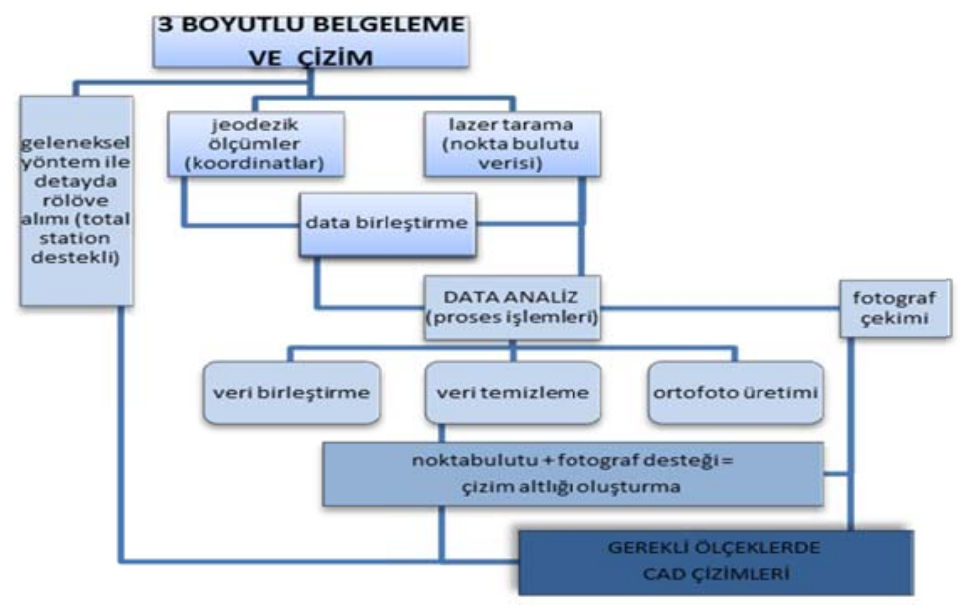

Şekil 19: Çalışma metodolojisi

Nokta bulutu ne kadar yoğun olur ise, yapının cephesindeki mimari detaylar örneğin pencere ve kapıyı çevreleyen profilli pervazlar, söveler, çıkmalar, cephedeki süslemeler, çatının altındaki bezemeler, saçak hizaları da o kadar net görülebilir. Mimari çizim üretilirken herhangi bir yoruma ihtiyaç duyulmadan, yapının cephesinin maksimum doğrulukta görülmesi önemli bir kriterdir. Yapı cephelerindeki çatlaklar, oyuklar, yüzey kaybına uğramış yüzeyler, biyolojik bozulmalar, kirlenmeler, 
Sudan Suakin Adasındaki Osmanlı Eserleri Mimari Özellikleri ve 3 Boyutlu Belgeleme Süreci

Architectural Characteristics of Ottoman Works and their 3 Dimensional Documentation Processes in Sulakin Island in Sudan

deformasyonlar yada önemli özellik arz eden kısımlar nokta bulutlarının üzerinden net seçilemediğinde, bu gibi durumlarda detay fotoğraflarından faydalanılmaktadır. Kalibre edilmiş fotoğraf makineleri ile elde edilen fotoğraflar, gerekli koordinatlara getirilerek nokta bulutları ile eşleştirilebilir ve böylece ayrıntı ve özellik arz eden yerlerdeki noktasal detaylar fotoğraf üzerinden takip edilebilir. Minarelerin şerefelerindeki bezemeler, gümrük binası ana giriş kapısındaki süslemeler ve Şafi Camisi'nin ayakta kalan mihrap ve minber detay çizimlerinde, yukarıda açıklandığı gibi ortofoto verilerinden faydalanıımıştır (Şekil 20).

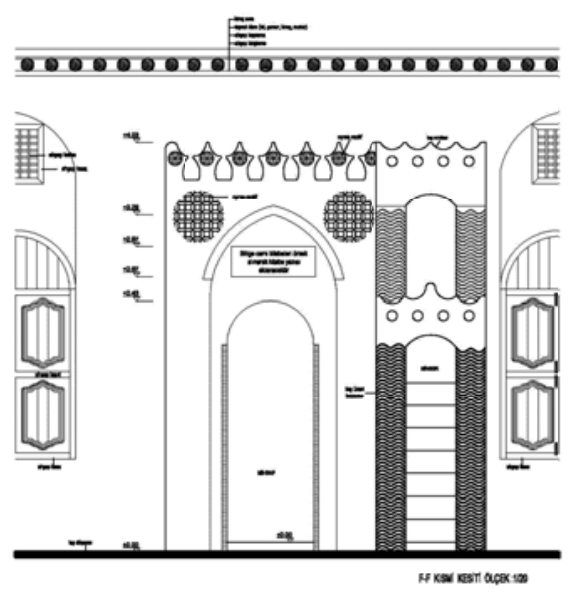

Şekil 20: Şafi Camisi mihrap detayı (nokta bulutu üzerinden yapılan örnek CAD çizimi)

\section{OSMANLI ESERLERININ BELGELENMESINDE 3 BOYUTLU LAZER TARAMA TEKNOLOJISININ SAĞLADIĞI KAZANIMLAR VE SONUÇ}

Suakin örneğinde, çalışma alanına ait cephe rölöveleri oluşturulurken, bitişik ya da yakın konumda bulunan diğer yapıların arasındaki mesafe, yükseklik ilişkisi, saçak ve çatı hizaları, bütünleşik haldeki nokta bulutu üzerinden rahatlıkla tespit edilebilmiş ve ölçümlenebilmiştir.

Arazide rölöve alımında gözden kaçan mimari detaylar (kırılmış pencere pervazı, saçak altındaki kopmuş bezeme, v.b.), cephelerin tümü dijital ortamda bir arada görülebildiğinden, ofis çalışmaları sırasında nokta bulutu üzerinden tamamlanabilmiştir.

Lazer tarama teknolojisi kullanımı, geleneksel yöntemle arazideki çalışma süresini \% 80 oranında azaltmış, cihazın gün ışığına ihtiyaç duyulmadan (gece saatlerinde) çalışabiliyor olması, arazide çalışılamayan gün sayısı (tecrübeller göz önüne alındığında) tüm iş gününün \%1'ini geçmemiştir. Rölöve ölçümlerinde lazer tarama teknolojisinin kullanılması, alanda yapılacak ölçüm süresini ve ölçüm doğruluğunu son derece olumlu etkilemiştir. Aynı zamanda nokta bulutu üzerinden alan ve hacim bilgisi elde etme imkanı, projenin eki olan metraj çalışmalarında da çok büyük zaman kazandırmıştır.

Sonuç olarak, lazer tarama teknolojisi kullanımı, insan işgücünü toplam iş üzerinden \%50 oranında azaltmış ve daha az sayıda (ancak uzman personel) ile rölöve alımı gerçekleştirilebilmiştir. Bu durum hem arazi, hem de ofisteki proje üretim ve teslim süresini olumlu etkilemiştir.

Kültürel varlıklar, ülke kimliğinin oluşmasında önemli roller üstlenirler. Bu değerlerin korunması, ülke kimliğinin korunması ve ulusal kimlik birlikteliğinin sağlanması ile eşdeğer olarak düşünülebilir. Ancak Sudan'ın içinde bulunduğu iç sıkıntılardan dolayı 
devletin buraya sahip çıkması zorlaşmış ve tahrip olan yapılar zamanla halk tarafından da terk edilmiştir. Limana ait resim ve çizimlerde şehrin eski halinin çok görkemli olduğu anlaşılmaktadır (Um, 2011, s. 44-47). Bu görkemli yerleşim maalesef yaşanan olumsuzluklar sonucunda günümüzde artık tamamen bir harabeye dönüşmüştür. Ada üzerinde 4-5'i dışında, ayakta kalan yapı neredeyse hiç yoktur. Zamanla yaşanan yağmalar ve doğa olayları da, binaları tamamen enkaz haline getirmiştir.

Bu yazı kapsamında aktarılan yapılar dışındaki diğer yapıların (konutlar, ticaret, eğitim, banka ve sağlık yapıları v.b.) envanter çalışmasının yapılması, mevcut durumlarının tespiti ve rölövelerinin elde edilmesi, dünya üzerindeki çok nadir olan bu kültürel mirasın gelecek nesillere aktarıması açısından gerekli ve elzemdir.

\section{TEŞEKKÜR}

2009-2010 yıllarında Suakin'de gerçekleştirilen rölöve, restitüsyon ve restorasyon projeleri hazırlanması işi kapsamında üretilmiş bilgi ve görselleri bu makalede kullanılması için izin veren Bimtaş A.Ş.'ye teşekkür ederiz. Suakin'de belgeleme ve rölöve alımı esnasında arazide görev yapan teknik ekipten; İnşaat Müh. Sertaç Kazıcı, Harita Müh. İhsan Altundaş, Harita Teknikeri Ferit Türel, Harita Teknikeri Osman Çetinpolat, Harita Teknikeri Vehbi Yılmaz, Y. Mimar Restorasyon Uzmanı Füsun Doğanyılmaz, Peyzaj Mimarı Beste Erel'e özverili çalışmalarından dolayı, tüm projelendirme çalışması esnasında bilgi, beceri ve desteklerini esirgemeyen Y. Mimar Tuna Kan, Y. Mimar Nergiz Başkaya, Y. Mimar Nazan Güçlü, Y. Şehir Plancı Emel Öztep'e ve bize bu imkanı tanıyan Bimtaş A.Ş. eski Genel Müd. Ahmet Ağırman'a teşekkür ederiz.

Gülhan Benli, Yeşim Dolunay Yüksel ve Serdar Ayan, 2009-2010 yıllarında hazırlanan, Sudan Suakin Gümrük Binası, Hanefi Cami ve Şafi Cami'lerinin Rölöve, Restitüsyon ve Restorasyon Projelerinde, proje müellifi olarak görev yapmıştır.

\section{KAYNAKLAR}

Arpa, Enver, TİKA Sudan Koordinatörü, "Sevakin Adası ve Osmanlı Yapıları Hakkında Rapor", 2009, s. 1-3.

Benli, Gülhan, Özer, G. Derya, "Use of Laser Scannıng For Cultural Heritage Documentation", IJEMME - International Journal of Electronics, Mechanical and Mechatronics Engineering, yıl 3, sayı 1, Türkiye 2013, s. 447-454.

Dahl, Gudrun and Hjort-af-ornas, Anders, "Precolonial Beja: a Periphery at the Crossroads", Nordic Journal of African Studies 15(4), Finlandiya 2006, s. 473-498.

Hale, Sondra, "Review of The Coral Buildings of Suakin (Boston 1976)", African Arts 10(4), The MIT press, ABD 1977, s. 5-8.

Greenlaw, Jean-Pierre, The Coral Buildings of Suakin, Stocksfield: Oriel Press. 1976.

Greenlaw, Jean Pierre, "The Island of Suakin: The History", The Kenana Handbook of Sudan, Ed.: Peter Gwynvay Hopkins, Routledge Pub., ABD, 2009, s.209-221.

Hamadai, A. Hamid, Suakin, the Port of Good Tidings. Khartoum: Sudan Ministry of Information and Culture, Sudan,1973, s. 5-8. 
Sudan Suakin Adasındaki Osmanlı Eserleri Mimari Özellikleri ve 3 Boyutlu Belgeleme Süreci Architectural Characteristics of Ottoman Works and their 3 Dimensional Documentation Processes in Suakin Island in Sudan

Hansen, E., "Preservation of Suakin", Unesco, Serial No: 2970/RMO.RD/CLP, OctoberNovember 1972, Paris, Fransa,1973, s. 1-5.

İBB Bimtaş A.Ş., Suakin Rölöve-Restitüsyon-Restorasyon proje raporları, 2010.

Mohammed, Abdelrahman Ali \& Welsby, Derek "Early States on the Nile: The Coming of Islam", The Sudan Handbook, Ed.: John Ryle, Justin Willis, Suliman Baldo, Jok Madut Jok, Rift Valley Institude, İngiltere, 2012, s. 69.

Rhodes, David, "The nineteenth-Century Colonial Archaeology of Suakin, Sudan", International Journal of Historical Archaeology, Springer, sayı 15, ABD 2011, s. 162189.

Roden, David, "The Twenties Century Decline Of Suakin", Sudan Notes and Records, sayı L1, Sudan, 1970, s.n.y.

Salim, Abdel Rahim, "Suakin: On Reviving an ancient Red Sea Port City", field report, Traditional Dwellings and Settlements Review, yıl 8, sayı 2. ABD, 1997, s.63-74.

Um, Nancy, "Greenlaw' Suakin, The Limits of Architectural Representation and the Continuing Lives of Buildings in Coastal Sudan", African Arts, The MIT press, ABD 2011, s. 36-51.

URL-1: https://www.google.com.tr/maps/place/Sudan / Erişim Tarihi: 01.09.2017 